\title{
A SHORT STORIES - BASED PROGRAM IN DEVELOPING SECOND YEAR UNIVERSITY STUDENTS' LEGAL VOCABULARY ACQUISITION AND READING COMPREHENSION
}

Said Fathy El Said Abdul Fattah

Assistant professor at Qassim Private Colleges, Saudi Arabia

\begin{abstract}
The present study was an attempt to determine the effectiveness of designing a program based on short stories to develop students' legal vocabulary. Participants were 100-second year college students, law department from a private university in Saudi Arabia. The experimental group $(\mathrm{N}=50)$ used short stories technique to develop their vocabulary acquisition; whereas the control group $(\mathrm{N}=50)$ was taught their vocabulary through their prescribed book. The pre-post test comprised three parts, the first part included reading a short story with ten questions related to this passage, the second comprised vocabulary questions and finally translation questions that included a list of words to be translated into Arabic and vice versa. Results of the $t$. test analysis revealed that the short stories techniques yielded significant effects on students' vocabulary acquisition, i.e. the experimental group outperformed the control group.
\end{abstract}

Key words: legal vocabulary, short story and vocabulary acquisition 


\section{Introduction}

As a result of spreading English language all over the world, a new field for teaching English language becomes one of the most common trends in learning and teaching English language. It is teaching English for specific purpose (ESP). This field is important for different fields like engineering, medicine, commerce, business, and law. Most of the lawyers and judges use specific vocabulary. This vocabulary is called academic vocabulary. Academic vocabulary, specifically the language that may occur in multiple contexts or the precise words that are presented in a specific context, can help students acquire new learning strategies and skills (Marzano, 2005). Academic writing is notably more difficult to learn than everyday language because it is more specific and sometimes abstract. The meaning of this vocabulary differs from one context to another (Sibold, 2011); hence, it becomes difficult to grasp. Knowledge of this kind of technical vocabulary in any specific content area-for example, social science, science, mathematics, or language arts - is directly linked to content knowledge.

In order to help students remember new words, teachers can ask English language learners (ELLS) to associate the new words with things that are already familiar to them, or the teacher can translate the words into the students' primary language (Colorado, 2007). It is important to connect the new vocabulary to students' prior knowledge. Vocabulary teaching and learning represents one of the major challenges to teachers and learners. Most of English language learners (ELLS) have difficulties in communicating with English language because of their limited vocabulary. In order to overcome these challenges they should use effective strategies that enhance vocabulary achievement. Academic vocabulary strategy refers 
to the words associated with the content knowledge. According to Parade (2012), within every discipline there is a specific set of words to represent its concepts and processes. These words are conceptually more complex than everyday language; therefore, they are more difficult to learn.

Vocabulary can be taught either directly through explicit instruction or indirectly through implicit instruction such as reading and discussion (AlZahrani, 2011). In addition, teachers can actively involve ELLs in learning new words, create a vocabulary rich environment, and teach through a variety of strategies. Teaching separated words or what is called word lists is not effective with students. One of the strategies used to teach academic vocabulary is using short stories.

\section{Short stories in language teaching}

Kallan (2000) describes the short story in structural terms as "a category of brief fiction, ranging in length from 55 words to 1,750 words. This 55word short story has certain features such as simple sentences, simple words and active verbs. Collie and Slater (1991) listed four advantages of using short stories for language teachers. First, short stories are practical as their length is long enough to cover entirely in one or two class sessions. Second, short stories are not complicated for students to work with on their own. Third, short stories have a variety of choice for different interests and tastes. Finally, short stories can be used with all levels (beginner to advance), all ages (young learners to adults) and all classes.

\section{Teaching reading through short stories}

Short stories are very useful in the trials to improve students' vocabulary and reading. For examples, Hismanoglu, (2001) \& Khatib \& 
Nasrollahi (2012) listed the following pedagogical advantages of shortstories over other literary texts. In this respect, short stories:

1. Make the students' reading task easier because they are simple and short

2. Give learners a better view of other people and other cultures

3. Require more attention and analysis that help students to be more creative

4. Raise students' critical thinking skills

5. Raise cultural awareness

6. Reduce students anxiety and help them feel more relaxed

7. Are good for multicultural contexts because of their universal language

8. Offera fictional and an interesting world

\section{Context of the problem}

Vocabulary has a central role in English language academic achievement. Acquiring vocabulary in a separated context is not effective. Therefore, there should be an effective link between vocabulary and reading comprehension of ESL / EFL learners (Chang, 2006). Through the researcher's teaching experience for teaching legal terminologies for department of law, it was noticed that this course depended mainly on memorizing legal terms. The students are asked only to translate some words or legal terms into Arabic and vice versa. 


\section{The Pilot Study}

\section{a. The students' questionnaire}

This questionnaire was administered to 100 students to determine their opinion towards the law terminology course and its effect upon them before conducting the program. The questionnaire simply consisted of the following five openended questions:

1. Do you think the previous English course was effective (Eng. 101)?

2. Do you remember ten words of the previous course? If so, write them down on the paper.

3. Have you ever used any English word you studied in your daily life?

4. Have you ever read a comprehension passage about law?

5. Do you like memorizing word lists in English regularly?

The questionnaire results were analyzed in the following table.

Table (1) Questionnaire results

\begin{tabular}{|c|l|l|}
\hline Question No. & $\begin{array}{l}\text { Percentage of positive } \\
\text { answers }\end{array}$ & $\begin{array}{l}\text { Percentage of negative } \\
\text { answers }\end{array}$ \\
\hline 1. & $6 \%$ & $94 \%$ \\
\hline 2. & $3 \%$ & $97 \%$ \\
\hline 3. & $5 \%$ & $95 \%$ \\
\hline 4. & $2 \%$ & $98 \%$ \\
\hline 5. & $10 \%$ & $90 \%$ \\
\hline
\end{tabular}


Analyzing the questionnaire results, the following are highlighted:

1. Nearly, most of the students thought that they learnt English and memorized some words to pass the exam only.

2. There were only three students who were able to write ten words correctly. Nine students wrote only seven right words while the others did not write could not write well.

3. Ten percent out of participants preferred to memorize word lists. They believed it was easier to them to get high marks without exerting much effort.

4. Eighty four students preferred short stories techniques in learning. They saw as an interesting technique.

Finally, this questionnaire showed that there was no real English language teaching for these students. Learning language is not only learning word lists.

\section{Statement of the Problem}

Thus, the study problem is identified in Saudi university-level EFL students' poor performance in understanding law terminological. Therefore, the current study attempted to develop these students' performance in legal terms and reading comprehension through using short stories. To reach this aim, the study tried to answer the following main question:

1. What is the effectiveness of a suggested short story based program in developing students' legal vocabulary acquisition and reading comprehension?

This main question is divided into the following sub-questions: 
1- What are the theoretical bases of teaching vocabulary through short stories?

2- What are the appropriate techniques and activities of teaching legal vocabulary and reading comprehension through short stories?

\section{Purpose of the study}

The purpose of this study was to investigate the effectiveness of a short stories based program on developing students' legal vocabulary and reading comprehension.

\section{The hypotheses of the study are:}

Hypotheses comparing the experimental groups and control groups mean scores on the posttest:

1. There would be significant differences in post-test mean scores of both the control and the experimental group in developing students' legal vocabulary in favour of those of the experimental group.

2. There would be significant differences in post-test mean scores of both the control and the experimental group in reading comprehension in favour of those of the experimental group.

Hypotheses comparing the experimental group mean scores before and after the treatment:

3. There is a statistically significant difference between the mean scores of the experimental groups on the pre-test and the post-test in developing legal vocabulary in favor of the post test. 
4. There is a statistically significant difference between the mean scores of the experimental groups on the pre-test and the post-test in reading comprehension in favor of the post test.

5. There is a statistically significant difference between the mean scores of the experimental groups on the pre-test and the post-test in students' attitude towards adopting short stories technique in favor of the post test.

\section{Review of literature}

Yang, (2009), is of the opinion that short stories are considered good resources that can be used in language classrooms. Laine (1997) suggests that in foreign language classes where there are children who are not motivated and who are low achievers, a story, if it is wellchosen, can help change their attitudes towards the language. Furthermore, the narrative (or storytelling) approach is believed to help students understand the story easily. Yang's study was conducted in a small class of junior secondary school students in order to investigate if they became more interested and more confident in English with the use of short stories. The findings of the study show that using short stories will not automatically make students become more interested in English unless the stories are interesting and the language used meets the level of the students. Findings also showed that students in general, favoured this approach as it helped them understand the stories easily, though their confidence in using English could not be boosted within a short period of time. 
Bouache (2010), attempts to investigate third year students' listening comprehension achievement in English language department in Constantine University. It aims at describing, and analyzing, what the listening skill involves, and showing how short stories can be used as a listening input within a communicative language-teaching framework. A test was used to investigate third year students' understanding and needs concerning the listening comprehension component of the oral expression course, as well as the listening input they had so far. The test also suggested the use of short stories as a listening input. Results showed that students were fond of using short stories as a listening input. Results also show that short stories constitute comprehensible input when they were presented via such an approach. They facilitated comprehension, developed critical thinking and encouraged learners' elaboration. Learners tended to relate the stories $^{\text {ee }}$ theme to their realities and to their personal experiences. Besides, the discourse of short stories had the advantage of presenting the components of communicative competence in a meaningful context as an input into use by non- native speakers.

Absullah \& Abu Bakar (2011) attempt to investigate second language learners' perception of the use of short stories in learning English. The study also attempts to determine students' level of interest in reading short stories, the problems faced by the students and the possible solution to those problems faced by students when short stories are used in the English language classroom. Questionnaires were distributed to second language learners taking Reading for Specific Purposes elective course in the Technological University in Malaysia. 
All the ninety two respondents were from three different sections from three different faculties and were from the engineering field. Data were triangulated through a questionnaire, an interview and observations. The findings showed positive patterns which indicated that the respondents have positive perception towards the use of short stories in learning, i.e., students were interested in the lessons that used short stories. In addition, the problems faced by the students, the strategies they used to deal with the problems and also the possible suggestions addressed to solve those problems were also identified. One of the major finding was students were interested to read short stories according to the theme that they preferred. Another major finding was that the main problem faced by the students was the problem of participation where they did not participate actively in the lessons that used short stories. This was due to low proficiency level and the theme of the short stories did not suit their interest. The students also suggested that short story should be assigned to be read before coming to class.

Pardede, (2012), assures the importance of using short stories in all language skills. He is of the opinion that recent trend in EFL teaching indicates the necessity of integrating literature because of its rich potential to provide an authentic model of language use. The purpose of this article is to familiarize EFL instructors with the effectiveness of using short stories in EFL instruction. After presenting criteria for selecting a short story, discussion is focused on how to exploit a short story for enhancing students' four language skills. 
In a similar vein, Pathan (2012 )advocates the use of short-stories for developing language skills. He argues that the use of short -stories offers the material which is real, creative and rich in language selection, as well as being amusing and motivational in nature., Pathan's also investigates the attitudes of the Libyan EFL learners towards the use of short-stories for developing reading comprehension skills. The present status of the use of short-stories in the Libyan EFL classrooms and the researcher's perspective on the use of short-stories in the Libyan context also form an important part of the discussion in his paper.

Pourkalhor, \& Kohan's study (2013), examined the impact of short story instruction of 20 advanced-level tenth-grade students on their reading comprehension. . To serve this purpose, an instrument was used in this study: a reading comprehension test that was administered to both the experimental ( taught via short stories) and the control group (taught via the traditional way of teaching reading comprehension).The data obtained from the instrument was analyzed using t- tests. The result showed that students in the experimental group did better on the comprehension test than those in the control group.

It is concluded from the above review that:

1. Adopting short stories in teaching English skills is one of the current trends in EFL or ESL.

2. This trend is not limited to specific culture. It is adopted all over the world.

Those studies had benefited the present study theoretically and practically in the following ways: 
a. Offering theoretical and practical guidelines to follow from the very beginning till the very end.

b. Designing the study tools that were used for data collection.

c. Research procedures to be followed on scientific bases.

d. The way data and results were analyzed and discussed.

\section{METHOD}

\section{Design}

The quasi-experimental design was used in this study, where two intact classes of the second year students in Law department were randomly assigned to the experimental and control group. A pre/post test was conducted to measure the effectiveness of the program.

\section{Participants}

The subjects of this study were (100) students in two intact classes who were randomly assigned to experimental group (N50) and control group (N50), in Qassim Private Colleges. The students were in the second year, level four, Law Department. They studied an English course called English for Legal Terminology (Eng. 102) This course seems to be like a dictionary containing a list of academic vocabulary in the field of law. They were enlisted with their Arabic meanings. Students are asked to memorize the terms with their meaning in the final exam. It was considered the most difficult course for them as shown from the results of the pilot study.. Their ages ranged between 18 to 35 years. 
- Both groups were administered the Pre-test which showed uniformity in the results, with very little variation that showed the two groups had similar vocabulary ability(For pretest results see, appendix 4)

Both the groups were instructed by two of the teachers for a full semester in the vocabulary courses that was designed for them.

\section{Instruments}

\section{a. Students' satisfaction questionnaire}

This satisfaction questionnaire was administered only to the experimental group to determine their satisfaction towards adopting short stories technique. Therefore, it was administered only to 50 students. This questionnaire included five items that took the form of a five-point Likert scale that ranged from "Strongly Agree", "Agree", "Neutral", "Disagree" and "Strongly Disagree". It included the following items:

1. I think learning vocabulary through short stories is interesting.

2. I think vocabulary becomes easier through short stories.

3. I think the suggested short stories were attractive.

4. I think I can learn English vocabulary by short stories.

5. I think short stories can motivate me to learn English.

To sustain the reliability and fidelity of this questionnaire, it is approved by expert's content validity test; two college assistant professors and two English teachers reviewed on the content. 


\section{b. The pre/post test}

A pre/post test was designed in the light of English for Law course that was prescribed for the students to study during the first semester of the academic year 2013-2014. Then, it was administered to the students of both the experimental and control groups to make sure that they were at the same level of performance before starting the experiment; and hence the progress achieved by the experimental group students could be attributed to the teaching program they received through using short stories. The pre-test was also used as a post-test to investigate the effectiveness of the suggested program based on short stories to develop students' legal vocabulary.

\section{Description of the test}

The pre-post test was constructed in the light of the following sources:

1- Reviewing previous studies concerned with vocabulary, especially those tackling the legal terms.

2- The following points were taken into account when writing the test items:

- The words and sentences used in the test items were simple, clear, and familiar to the students.

- The items were relevant to the objectives of the test.

\section{The Content of the test}

The test consisted of three questions;

1. Reading Comprehension. 
The students were asked to answer some questions related to the reading passages. It was about a simple short story describing a crime action in the street. It consists of ten questions; the first five questions are multiple choices that related to the reading passages and the others are whquestions.

2. Fill in the space

Students are asked to fill the spaces with suitable words from a word list.

3. Supply the missing parts

Students are asked to supply the missing words in the passage.

4. Match

The students match the term with its definition in English.

The total marks of this test was (40) marks.

\section{Validity of the test}

To measure the test content validity, the first version of the test was given to $2 \mathrm{EFL}$ assistant professors and $2 \mathrm{EFL}$ lecturers to evaluate appropriateness of each item in measuring their learning legal vocabulary. Moreover, they were requested to evaluate the test as a whole in

terms of: (a) correctness, (b) number of items, and (c) suitability of the test items to level four EFL students at Qassim Private Colleges.

The test proved to be mostly valid as the jury approved most of the questions and suggested the following: 
1. Putting legal terms in context. Therefore, the students fill in the space with suitable words and there is translation.

2. Adding a fourth question for the exam. It is a matching questions. The students were asked to match a word from a column (a) with its meaning from the column (b).

\section{Piloting the test}

Piloting the test aimed at (a) determining reliability of the test; and (b) determining the suitable time to be allotted for the test; Therefore, 30 students were selected for the pilot study. These students were randomly selected who belonged neither to the experimental group nor to the control group. They were excluded from the whole treatment.

\section{Test reliability}

The test was administered to a randomly selected group of 30 students. Then, the test was administered one more time after two weeks to the same 30 students. The Pearson correlation coefficient between the test/re-test results was calculated. The reliability coefficient was 0.89 , which is relatively high. Therefore, the test could be considered a reliable one for the purpose of the current study.

\section{Test time}

It was estimated that one classroom period (approximately 75 minutes) would provide ample time for the students to read the test questions and write their answers. This time was calculated in the following way: 
The time taken by the fastest student + the time taken by the slowest student

$\frac{40+110}{2} \quad=75$ minutes

\section{c. The Program}

\section{Duration}

The course lasted for sixty days from the sixth of October till the twenty sixth of December, 2013. The meeting was two hours a week with a total of sixteen hours. Both groups were instructed by two of the teachers for a full semester in the vocabulary courses that was designed for them.

\section{Aims of the program}

1. Encourage students to take part in legal Academic course for developing their vocabulary and reading comprehension.

2. Attract students' attention to learn vocabulary through short stories.

\section{Content of the program}

This program was divided into eight chapters. Each chapter comprised the following:

\section{Legal terms}

It includes the legal terms with their definitions. Then it was followed by different exercises.

\section{Short story}

This short story includes the previous legal terms. It was characterized by its simple language, structure and brief context. 


\section{Ask and answer}

This part included long and short questions about the short story.

\section{Vocabulary exercise}

This part included exercises on the previous legal terms. These exercises depended on students' understanding of the terms. They transferred their understanding to different context.

\section{Validity of the program}

To measure the test content validity, the first version of the test was given to $2 \mathrm{EFL}$ assistant professors to evaluate appropriateness of the program in the light of its objectives. They made change in questions types and the content of reading passages.

\section{Results}

Results of this study would be reported in terms of the study hypothesis.

\section{Hypothesis one}

It stated: there were significant differences in the posttest results between the mean score of the control and experimental group after conducting the experiment in learning legal vocabulary in favour of the experimental group.

To test this hypothesis, t-test for independent samples was conducted to compare the means between the experimental and control groups. 
Table (2)Post test results between control and experimental groups in legal vocabulary

\begin{tabular}{|l|c|c|c|r|r|r|}
\hline Group & $\mathbf{N}$ & $\mathbf{M}$ & S.D. & $\begin{array}{c}\text { Std. } \\
\text { Error } \\
\text { Mean }\end{array}$ & $\begin{array}{c}\mathbf{t} \\
\text { value }\end{array}$ & $\begin{array}{c}\text { Sig. (2- } \\
\text { tailed) }\end{array}$ \\
\cline { 1 - 5 } $\begin{array}{l}\text { Experiment } \\
\text { al }\end{array}$ & 50 & $\begin{array}{c}27.7 \\
0\end{array}$ & 8.87 & 1.25 & & \\
\cline { 1 - 5 } Control & 50 & $\begin{array}{c}20.1 \\
8\end{array}$ & 6.85 & .97 & & .488 \\
\hline
\end{tabular}

Then the t. test was computed between the two groups. Observed t. value is (4.742) while the value of the tabulated $t$ at the level (0.01) i. It showed that $\underline{t}$ value obtained from the posttest was more than $\mathrm{t}$ table value. This means that there were significant differences between the mean score of the control group and the experimental group after conducting the experiment in developing legal vocabulary in the favour of the experimental group. Hence, the first hypothesis was verified.

\section{Hypothesis Two}

There is a significant difference in post-test mean scores of both the control and the experimental group in reading comprehension in favour of those of the experimental group.

To test this hypothesis, t test for independent samples were conducted to compare the means between the experimental and control groups. 
Table (3) Post test results between control and experimental groups in reading comprehension

\begin{tabular}{|l|c|c|c|c|c|r|}
\hline Group & $\mathbf{N}$ & $\mathbf{M}$ & S.D. & $\begin{array}{c}\text { Std. } \\
\text { Error } \\
\text { Mean }\end{array}$ & $\begin{array}{c}\mathbf{t} \\
\text { value }\end{array}$ & $\begin{array}{c}\text { Sig. (2- } \\
\text { tailed) }\end{array}$ \\
\hline $\begin{array}{l}\text { Experiment } \\
\text { al }\end{array}$ & 50 & $\begin{array}{c}31.3 \\
4\end{array}$ & 8.093 & 1.13 & & \\
\cline { 1 - 5 } Control & 50 & $\begin{array}{c}22.3 \\
2\end{array}$ & 5.93 & .84 & 6.381 & .447 \\
\hline
\end{tabular}

Then the t. test was computed between the two groups. Observed t. value, (6.381) with the value of the tabulated $\underline{t}$ at the level (0.01) was .447. It showed that $\mathrm{t}$ value obtained from the posttest was more than $\mathrm{t}$ table value. This means that there were significant differences between the mean score of the control group and the experimental group after conducting the experiment in developing legal vocabulary in the favour of the experimental group. Hence, the second hypothesis stated that there would be significant differences in posttest mean scores of both the control and the experimental group in developing reading comprehension in favour of those of the experimental group, was verified.

\section{Hypothesis three}

There were statistically significant differences between the mean scores of the experimental group on the pre-test and the post-test in developing legal vocabulary in favor of the post test. 
To test the above hypothesis, the paired samples t-test was used, and the results are shown in table (4) below.

Table (4): t- Test results comparing the experimental group students' performance on the pre-test versus the post-test in legal vocabulary

\begin{tabular}{|c|c|c|c|c|c|c|}
\hline Group & $\mathbf{N}$ & $\mathbf{M}$ & S.D. & $\begin{array}{c}\text { Std. } \\
\text { Error } \\
\text { Mean }\end{array}$ & $\begin{array}{c}\mathbf{t} \\
\text { value }\end{array}$ & $\begin{array}{l}\text { Sig. (2- } \\
\text { tailed) }\end{array}$ \\
\hline pre-test & 50 & 18.36 & 6.68 & .945 & \multirow{2}{*}{7.863} & \multirow{2}{*}{.00} \\
\hline post-test & 50 & 27.70 & 8.87 & 1.25 & & \\
\hline
\end{tabular}

Then the t. test was computed between the pretest and the posttest. Observed $t$. value, (7.863) with the value of the tabulated $t$ at the level (0.01) was .000. It showed that $\underline{t}$ value obtained from the posttest was more than $\mathrm{t}$ table value. Hence, the third hypothesis stated that There is a statistically significant difference between the mean scores of the experimental groups on the pre-test and the post-test in legal vocabulary in favor of the post test was verified.

\section{Hypothesis four}

There is a statistically significant difference between the mean scores of the experimental group on the pre-test and the post-test in reading comprehension in favor of the post test.

To test the above hypothesis, the paired samples t-test was used, and the results are shown in table (5) below. 
Table (5): $t-$ Test results comparing the experimental group students' performance on the pre-test versus the post-test in reading comprehension

\begin{tabular}{|l|c|c|c|c|c|c|}
\hline Group & $\mathbf{N}$ & $\mathbf{M}$ & S.D. & $\begin{array}{c}\text { Std. } \\
\text { Error } \\
\text { Mean }\end{array}$ & $\begin{array}{c}\mathbf{t} \\
\text { value }\end{array}$ & $\begin{array}{c}\text { Sig. (2- } \\
\text { tailed) }\end{array}$ \\
\hline pre-test & 50 & 18.26 & 7.92 & 1.12 & \multirow{2}{*}{9.745} & .00 \\
\hline post-test & 50 & 31.34 & 8.039 & 1.13 & & \multirow{2}{*}{. } \\
\hline
\end{tabular}

Then the t. test was computed between the pretest and the posttest. Observed t. value, (9.745) with the value of the tabulated $\underline{t}$ at the level (0.01) was .000. It showed that $\mathrm{t}$ value obtained from the posttest was more than t table value. Hence, the third hypothesis stated that There were statistically significant differences between the mean scores of the experimental groups on the pre-test and the post-test in reading comprehension in favor of the post test was verified.

\section{Hypothesis five}

There is a statistically significant difference between the mean scores of the experimental group on the pre-test and the post-test in students' satisfaction towards adopting short story technique in favor of the post test.

To test the above hypothesis, the paired samples t-test was used, and the results are shown in table (6) below. 
Table (6) Results of the Experimental Group Satisfaction Questionnaire

\begin{tabular}{|c|c|c|c|c|c|c|c|}
\hline Q. N. & Test & $\mathbf{N}$ & Mean & SD & $\begin{array}{l}\text { St } \\
\text { d. Error } \\
\text { Mean }\end{array}$ & t value & $\begin{array}{l}\text { Sig. (2- } \\
\text { tailed) }\end{array}$ \\
\hline \multirow[t]{2}{*}{1.} & Pretest & 0 & E 1.9000 & .93131 & .13171 & 14.426 & .000 \\
\hline & $\begin{array}{ll} & \text { Postt } \\
\text { est } & \end{array}$ & 50 & 3.7600 & 1.00122 & 14159 & 26.555 & .000 \\
\hline \multirow[t]{2}{*}{2.} & Pretest & 50 & 2.1400 & .92604 & .13096 & 16.341 & .000 \\
\hline & Postt & 50 & 4.1200 & .79898 & .11299 & 36.463 & .000 \\
\hline \multirow[t]{2}{*}{3.} & Pretest & 50 & 2.0000 & 1.06904 & .15119 & 13.229 & .000 \\
\hline & Postt & 50 & 3.9000 & .78895 & .11157 & 34.954 & .000 \\
\hline \multirow[t]{2}{*}{4.} & Pretest & 50 & 1.6000 & .60609 & .08571 & 18.667 & .000 \\
\hline & Postt & 50 & 3.9800 & 1.03982 & .14705 & 27.065 & .000 \\
\hline \multirow[t]{2}{*}{5.} & Pretest & 50 & 1.8400 & .58414 & .08261 & 22.273 & .000 \\
\hline & Postt & 50 & 3.9000 & 1.09265 & .15452 & 14.426 & .000 \\
\hline
\end{tabular}

The $\mathrm{t}$. test was computed between the pretest and the posttest. Observed t. value compared with the value of the tabulated $\underline{t}$ at the level (0.01) was .000 in all five questions. It showed that $\mathrm{t}$ value obtained from the posttest was more than $\mathrm{t}$ table value. Hence, the fifth hypothesis that test was verified. 
To sum up, the five hypotheses of the study were supported by the results. The statistical analyses of data indicate that the experimental group students who used short stories technique performed much better on the post-test in legal vocabulary and reading comprehension than the students who received regular law course. Moreover, the experimental group students achieved significant progress in their awareness of legal vocabulary and reading comprehension after the treatment as compared to performance before the treatment. Hence, these positive findings proved the effectiveness of adopting short stories technique in developing university students' vocabulary and reading comprehension.

\section{Discussion and Conclusion}

The ability to understand a text is based not only on the students' abilities to memorize word lists, but also on general knowledge of the world and the extent to which that knowledge is activated during processing. Depending on the word list alone is not the only way of dealing with vocabulary. At the same time, teaching vocabulary out of language skills is not effective. The meaning of a word may differ from one context to another. Therefore, there is a kind of relation between reading and vocabulary.

The result of this study was in line with Yang, 2009, in his findings when he stated that using short stories, in general would not make students interested in learning English easily unless the stories and the language used meets students' level. In this study, the short stories chosen in this study were attractive to them. All 
of the short stories were related to their field. Mostly, they are detective stories full of actions and

suspense. Students' attention and motivation were aroused during the short story to know what would happen in the end.

In addition to Yang, the results of this study was in line with those of Bouache, (2010) who asserted that learners tend to relate the story themes to their realities and to their personal experience. During conducting this study, some of the students reported their experience to others. Some of them reported about traffic accidents or crimes they heard about. Some of the older students spoke about their cases in the court. Hence, there was a real interaction and communication inside the class which, undoubtedly, increased students' retention of the vocabulary presented.

The results of this study shares the importance of using short stories in the ESP field with those of Absullah \& Abu Baker, (2011). They used short stories for second language learner taking ESP as elective courses. However, this study was different in dealing directly with an obligatory subject to Law Department.

Also, the results of this study agree with those of Pathan's, results (2012) who investigated the attitudes of Libyan EFL learners towards the use of short stories for developing reading comprehension. Students' satisfaction with the new technique was crucial in this study as shown by the questionnaire results The students were attracted by the short stories. They felt that 
they became a part of English class. They were eager to know the end of the each story. Therefore, they tried to do their best to follow the theme and events. In addition to that students began gradually to learn legal terminologies that represented a part of this program. The students were asked about their opinion in adopting short stories in learning English language. Nearly, 92\% of the students supported this technique in teaching.

The result of this studies and the view of reading comprehension as an interactive process between the reader and the text leads to the improvement of vocabulary. This study found that most of the respondents in the experimental group showed improvement in their vocabulary. The experimental group showed a significant difference in its posttest.

It was noticed that there were some the students; nearly in the experimental group had some difficulty following the program. That was due to their English

proficiency. Those were provided special help on the part of the instructor. In addition, it was very important to make a balance between the language of the selected short stories and students' level. The program of this study moves gradually from easy to difficult short stories so that all students could catch up.

Finally, Most of the students remembered vocabulary terms through relating them to the short story actions. Results of the study found sufficient reasons for teaching vocabulary through short stories in Law Departments. 


\section{Recommendations}

In light of the finding of the present study, the following recommendations seem pertinent:

1. Devoting part of legal English courses to the use of short stories so as to increase students motivation and satisfaction with their learning.

2. Giving students the chance to express their own short stories orally or in writing. During this process, teachers should be tolerant in dealing with their students' errors.

3. Learning legal vocabulary should not rely on memorizing word lists. These words should be put in authentic contexts such as short stories to be understood because the context of the word defines its meaning.

4. Encouraging the adoption of the short story technique in developing other language skills such as writing and speaking.

5. Replicating this study in other specializations and in different educational levels.

\section{References}

- Absullah, T. \&Abu Bakar, N. (2011). "A study on second language learners' perception of using short story in learning English". JET, 18, 1, (1), February, 2011.pp. 1-8

- Al-Zahrani, M. (2011). "The Effectiveness of Keyword-based Instruction in Enhancing English Vocabulary Achievement and Retention of Intermediate Stage Pupils with Different Working 
Memory Capacities". Unpublished PhD. Thesis, Taif University, KSA.

- Bouache, R.(2010). "The Impact of listening to short stories on listening". Unpublished MA. Thesis,Mentouri University, Constantine Faculty of letters Department of foreign languages,Algeria.

- Chang, Y. (2006). "Visual Organizers as Scaffolds in Teaching English as a Foreign Language". Retrieved from Eric. ED494210

- Collie, J., and Slater, S. (1991). Literature in the Language Classroom. (5th Ed.). Glasgow: Cambridge University Press.

- Colorado, C. (2007). "Vocabulary development with ELLs". Retrieved January 31, 2010, from http://www.readingrockets.org/articles/ 32556

- Hismanoglu, M. (2001). Teaching English through literature. Journal of Language and Linguistic Studies, 1(1), 53-66.

- Kallan, R. (2006). "Teaching Journalistic Cogency with 55-Word Short Stories."Journalism and Mass Communication Educator: 81-88.

- Khatib, S. (2011). Applying the reader-response approach in teaching English short Stories to EFL students. Journal of Language Teaching and Research, 2(1), 151-159.

- Laine, E. (1997). The place of story- telling in English Language Teaching. In P. Falvey. \& P. Kennedy. (EDs.), learning Language through literature: a source book for teachers of English in Hong Kong (pp. 65-72). Hong Kong: Hong Kong University press. 
- Lao, C. \&Krashen, S. (2000)."The impact of popular literature study on literacy development in EFL: More evidence for the power of reading. System", 28(2), 261-270.

- Marzano, R. (2004). Essential knowledge: The debate over what American students know. Aurora, CO: Mid-continent Research for Education and Learning.

- Pardede, P. (2012). Using short stories to teach language skills. Retrieved 12 July 2012, from http://parlindunganpardede.wordpress.com/articles/languageteaching/using-short- stories-to-teach-language-skills

- Pourkalhor, O. \& Kohan, N. (2013). Teaching reading comprehension through short stories in advance classes. Asian journal of social sciences \& humanities, vol. 2 no. 2 May 2013

- Sibold, C. (2011) Building English Language Learners' Academic Vocabulary: Strategies and Tips. Multicultural Education, v18 n2 p24-28 Win 2011

- Yang, C. (2009). A Case Study of the use of Short Stories in a Junior Secondary ESL Classroom in Hong Kong. International Journal of Learning;2009, Vol. 16 Issue 1, p35 